\title{
The application problem of internet and multimedia technologies in modern theatre in Azerbaijan
}

\author{
Elshad Aliyev ${ }^{1}$
}

1 Assoc Prof., ANAS The Institute of Architecture and Art, Department of "Culturology and Art Theory", AZERBAIJAN, E-mail: aliyev.science@gmail.com

\begin{abstract}
Almost all fields of art intersect in the theatre. From this point of view, the theatre is a unique place. It's been decades that creative people working in the field of theatre try to use new technologies whenever possible. Various types of spectacles, show and performances are created using constantly evolving Internet technologies and multi-media.V arious types of digital equipment, devices, computer programs, gadgets and internet technologies are used in scenography, music and lighting. The application problems of information and communication technologies in the theatre make modern theatre critics think and lead to certain predictions about the future of the theatre. In any case, new multimedia technologies are already becoming an integral part of theatrical art
\end{abstract}

Keywords: Modern Theatre, ICT, Cyber Theatre, Scenography, Digital Art 


\section{INTRODUCTION}

Almost all fields of art intersect in the theatre. From this point of view, the theatre is a unique place. Besides the playwright, director and actor, choreographer, artist, composer and other creative people contributed to the creation of the spectacle on the stage. Since the end of the 19th century, the director has been the leading force of the theatre and his opinion dominates during the preparation of the spectacle. The constant creative research of theatre directors with an innovative spirit leads to an increase of interest in new media technologies. Besides the directors, other creative people, artists, composers, sound and light designers participated in the composition of the spectacle in the theatre are experimenting modern technological innovations, which lead to the emergence of completely new artistic solutions.

From time to time, new technologies enter the theatre and are increasingly used in spectacles. Various types of spectacles, shows and performances are created using the constantly evolving Internet technologies and multi-media means. Although certain aspects of the application problem of the Internet and multimedia technologies in modern theatre are actively studied by many modern researchers, Azerbaijani art critics, theatre specialists and theatre critics have not paid much attention to the issue. Mainly many researchers in the West have studied the use of information and communication technologies in scenography and various aspects of their application in theatre in general and the problem has been involved in serious art research. Thus, from time to time, A.M.Monteverdi, C. Papagiannouli, A.Abrahams, H.W.Yamieson,
M.Chatzichristodoulou, D.Punjani and other researchers and theatre critics have been closely engaged in this problem.

Our research shows that the fields of the art are divided into several groups depending on information technologies. Fields of art that have been created with the use of certain digital equipment and computers and replicated and demonstrated in the futuredepend on information technology. Cinematography, digital painting or digital music can be shown as fields of art.

Another group is the fields of art, which have no dependence on information and communication technology means. This includes more decorative applied arts. For example, pottery, carpet weaving, tapestry, also instrumental and solo performances (e.g.saz performance). This type of art does not depend on the development of information technology and operates independently.

The third group is the fields of art that do not depend on information and communication technology means but have access and are demonstrated to the international "market" with the help of information and communication technology. As a rule, all fields of art can be attributed here. The end result of digital painting, pottery, which does not depend on information technology, i.e. the "art product" can eventually be displayed on the Internet, stored on various electronic carriers or Internet databases, and passed on to future generations.For example, the development of digital equipment and its use in music do not impact on the art of ashug. Ashugs create and eternalize their art through a few strings, as they did

Picture 1. Graph Showing the Dependence of Various Fields of Art on Information and Communication Technologies

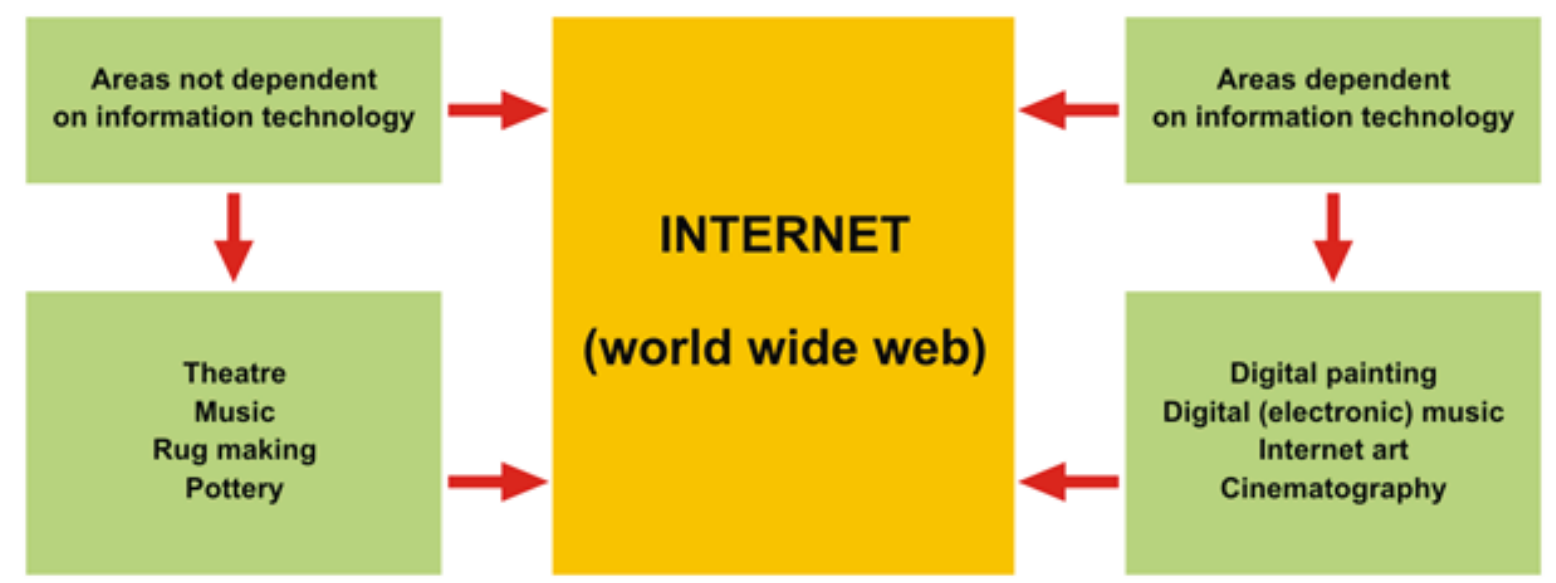


a few hundred years ago.B ut, the performance of ashugs is recorded with digital equipment and posted on the international electronic network. It is possible to listen to the performance of ashugs, see their appearance and dance anywhere on the world through the Youtube portal. In other words, the product of art created without the use of information technology can eventually be introduced to the whole world with the help of Internet technologies. In this regard, for the first time, we demonstrate the dependence of the fields of art on information and communication technology through the following graph (pic. 1).

Theatre in itself is a field of art that does not depend on information technology. In other words, it is possible to prepare a spectacle and bring it to a wide audience without the use of any media technology. Especially we can see this clearly in the example of Shakespeare's Globe Theatre in England. The theatre's staff, which is located in London, England, travels to different countries throughout the year. The main peculiarity of the theatre is the use of information technology as little as possible (Aliyev, 2016: 15). The main purpose of this theatre is to preserve and eternalize the atmosphere and spirit of Shakespeare's time. But, innovative technologies are applied in the field of theatre, as in all areas of our time and yield very interesting results. Various types of digital equipment, computer programs and applications are successfully used in lighting and sound design in spectacles.

Towards the end of the last century, pessimistic predictions about the future of theatrical art were heard, while scientific and technological progress showed unexpected results year after year.It is said that theatrical art will be oppressed by cinematography and television and it was said that the future of theatrical art would become increasingly dark over time. Rodion (cinematographer), one of the protagonists of cinema-producer Vladimir Menshov's world-famous melodramatic film "Moscow Doesn't Believe in Tears" demonstrated in 1979 talks excitedly about the future of television at a meeting (Ulanova, 2019). The young cameraman Rodion predicts that television will completely change the future of humanity, there will be no theatre, cinematography, books and newspapers and there will be only television everywhere. It is also interesting how another young man participated at the meeting reacted to Rodio's forecast for the future.He emphasized that the theatre would indeed "die" soon, but did not agree with the opinion of his interlocutor about movies and books. Rodion advised his interlocutors to remember what they said about television 20 years later. Probably, neither the film's screenwriter V. Chernykh nor others who worked on the film could have imagined that it would be the Internet, not television everywhere, even in the pocket of each of us about 30-40 years later. Unlike the prediction in the film, neither the theatre nor the cinematography has disappeared, on the contrary it has reached a completely new stage with the help of modern digital technologies and sometimes Internet resources.

\section{CYBER THEATRE}

Since the early 90s of the last century, theatrical figures have begun to carry out different experiments, to create new alternative spectacles with Internet technology and as a result, new theatrical forms have emerged. This new art phenomenon is expressed in various terms such as intermedial performance, virtual theatre, cyber drama, cyber performance, digital performance, hyperformance, online theatre, internet performance. In general, theatre and art representatives still do not welcome this new stream of art in terms of art criticism (Papagiannouli, 2011: 273-282).

For the first time, Barry Smith and Steve Dixon used the term "Digital performance" in 2001, when they launched the "Digital Performance Archive" project. According to them, the term of digital performance covers everything from spectacles composed with the help of new technologies, live theatre and dance productions created through the digital projections to spectacles on a computer screen, webcasting and interactive virtual environment (Chatzichristodoulou, 2014: 19-31).

In general, various terms have been used to express spectacles, theatre groups and performances by the use of information technology in recent years. Terms such as cyberstage, cyberspace, digital theatre, media theatre, etc. are used to describe new forms and theatrical spaces created with the help of media technologies. Thus, not only the theatre stage, but also any space can be a cyber scene with the help of new technologies. That is, the whole world is a Cyber scene and at the same time the whole cyber world is a kind of scene.The theatre stage is becoming a completely new and wider cyber environment moving beyond limited borders with the help of Internet resources and applications, software and various digital platforms.

It should be noted that the ideas of Italian art historian, 
specialist on digital performance and video theatre, expert Anna Monteverdi are especially interesting. She believes that today the computer has become an important tool, an agent of performative action and creativity. Cyber theatre is a metaphor of the anthropological evolution of the body in which machine and human can coexist. In fact, the sense of technology has changed or distorted the ideas of reality, being, and vitality. Digital performance can determine the turning point of the theatre and invent new forms of transportation (2010: 280).

Today, modern visual technologies are widely studied, tested and applied in conjunction with traditional theatrical methods in theatres. For this reason, it is becoming difficult to distinguish and analyze the boundaries and spaces that exist in the theatre space. We think that multimedia technologies will expand the imaginary performance space of the stage through breaking down borders and creating a new multilayered environment in the near future. In addition, multimedia spectacles and projections can be shown anywhere in the theatre, even outside the theatre building. Interestingly, thanks to the Internet, such spectacles can be distantly controlled even by an IT engineer, theatre artist and sound director living and working in another city. Of course, this factor will not only create new opportunities, but also create certain difficulties.

It is important to note that besides Internet technologies, various types of modern digital devices, computer programs, lighting and sound equipment allow to realize even the most fantastic ideas of the director in the theatre space. Sound and light effects, which were once impossible, are being successfully applied with the use of new media technologies. Of course, progressive-minded directors should collaborate with IT engineers and programmers to achieve original and eye-catching results that meet higher artistic tastes. It is no coincidence that media technologies are already taught in universities that provide theatre education in different countries around the world.

Our research shows that theatre figures use new technologies more widely and successfully in advanced countries where information and communication and computer technologies are produced. For example, there have been creative theatre groups and collectives that create spectacles using only new technologies, projections and multimedia means for many years in South Korea, Japan, USA and Germany (pic. 2). It is already possible to see spectacles of such theatres at various high-level international festivals.

Picture 2: Dancer Bends Light in Stunning ProjectionMapped Performance

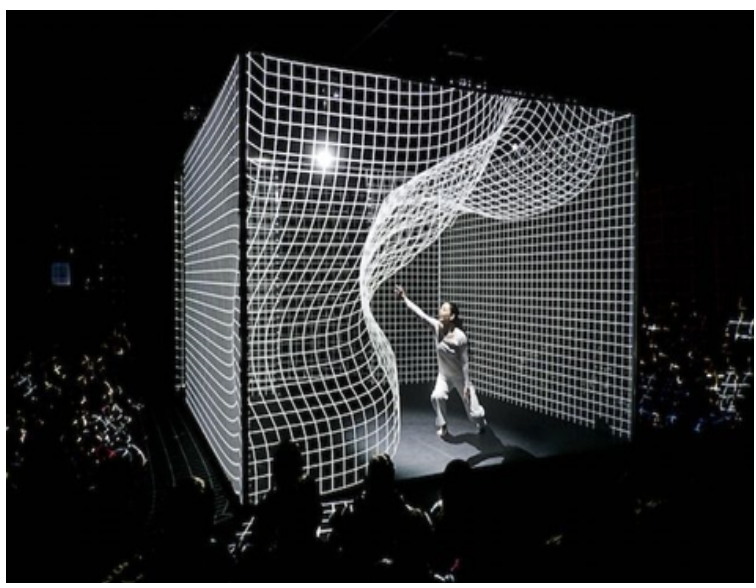

Source: https://www.vice.com/en/article/ez5pmp/dancer-bendslight-in-stunning-projection-mapped-performance

Today, the complex relationship of art and technology has taken such forms especially in theatre that theatrical aesthetics is almost entirely determined by the technological basis (Galkin, 2008: 50-75).

Theatre critic Cristina Papagiannoli's opinion is very interesting in this regard: "Theatrenot only as a form of entertainment, but also as a social art should use this interactive digital world as a political movement that reflects the world in which we live. In this regard, theatre figures and practitioners should look for new ways for structure of performances in Internet technologies. At the same time, performance, in its turn, must take into account the rapid change in technological achievements (2011: 273-282).

The use of computer programs as a scenography tool and material influences the artist's style and thinking. At the same time, the artist, who is looking for more expressiveness, influences the development of the visual opportunities of computer technology. The stageartist and researcher T. Astavyeva, who voiced this opinion, divides the artists who use computer means in their work into two types. The first type is "Media Art" artists. For these artists, the object of reflection is not the real world, but the media image created by the media, i.e. the core of the media world. The second type is a programmer-artist. The works of programmer-artists remind more abstract compositions. This is because their artistic solutions 
are based on lines and geometric figures. Programmerartist "draws" with ready-made samples and resources by means of computer programs (2011: 129).

The achievements of new technologies stimulate significantly the development of modern scenography. These achievements, in their turn, give opportunity to create a new artistic synthesis in solutions of scenography. Today, the use of various digital devices, screens and video projections controlled by computer programs are the dominant means of expression in light and image design. Digital means are replacing the traditional tools and materials used by the theatre artist. It is with the help of these means that certain, sometimes unusual, fantastic atmosphere is created on the stage in accordance with the ideas and artistic solutions. But to get all these ideas and visual solutions, the stage must be equipped with the necessary equipment, light and sound directors, media and programmers-artists must be skilled enough.

The use of various new technologies in scenography remains disputed matter. Of course, computer effects can increase the number of means of artistic expression in the theatre. But at the same time, the imbalance of visual technology with artistic elements can eventually make the spectacle look like a frame from a film or a cheap illustration (Bobrovskaya, Galkin, Sameeva, 2013: 104). It should be taken into account that the audience comes to the theatre to see live art. The spectator could go to the cinema to see fantastic scenes "enriched" with visual effects.

New technologies have changed the image of theatrical art so much that theatre critics are forced to emphasize that it is no longer possible to work in the traditional way (Josette, 2011: 54-64). So, speaking about the work of the Mumbai Theatre at the 27th Congress of the International Association of Theatre Critics (IATC, October 2014) in China, Indian art critic Deepa Punjani said that critics of theatrical performances, which are made with high-tech, should also take a new approach to this artistic criticism (2014).

\section{THE STATE OF APPLICATION OF ICT IN THEATRE IN AZERBAIJAN}

As already mentioned, many researchers have studied the use of information and communication technologies in scenography and generally various aspects of their application in theatre from time to time. Although certain aspects of the problem are actively studied by many modern researchers, Azerbaijani art critics, theatre specialists and theatre critics have not paid much attention to the issue.

Recently, certain laws have been adopted and serious measures have been taken in order to ensure the development of theatre in Azerbaijan. It should be noted that the adoption of the "Law on Theatre and Theatre Activity" in 2006 laid the ground for the signing of the decree "On the development of theatre art in Azerbaijan" in 2007. The "State Program for the Development of the Azerbaijani Theatre in 2009-2019" stimulated the measures to be taken in connection with the development of both the Ministry of Culture and Tourism and the national theatre of Azerbaijan. As a result of all this, the buildings of theatres in the country have been reconstructed thoroughly and each time their material and technical base is updated after such reconstruction and associated to modern times and technologies. For example, the building of the Academic National Drama Theatre was commissioned in 2011 after a major reconstruction. The theatre is equipped with various types of equipment based on new technologies, including sound equipment made in Germany. This equipment is a sample of the most advanced technologies. Specialists of the manufacturer can solve various types of complex faults in such equipment from a long distance by accessing the IP address of the theatre. It is even possible to stop using this equipment from thousands of kilometers away. All this is a clear sign of the dependence of modern theatre on information and communication technologies. Taking account that this type of equipment is quite expensive, it is important to have local professionals to overcome such technical difficulties in the future.

Today, various new technologies are used in the preparation of backcloth and decorations used in Azerbaijani theatres. Digital sketches prepared by a theatre artist staging a spectacle can be pre-printed on various types of materials using proper printers. The initial sketch of the scenography can also be done in advance on a digital platform, a digital tablet. 3D (three-dimensional) printers can also be used to make decorations and properties. The use of such technologies makes the spectacles well-conditioned. Different types of lighting technologies also caress the taste of the audience.

As we have noted, the State Program "Azerbaijan Theatre in 2009-2019" was adopted by the order of the President of the Republic of Azerbaijan and for the first time the first Baku International Theatre Conference on "The World Theatre Process in the 21stCentury: 
Problems, Perspectives and Alternatives" was held on November 8-10, 2010 within the framework of this program. At the same time, it shows the tendencies of the Azerbaijani theatre to integrate into the world theatre space. It is gratifying that we see the introduction of new technologies in the theatrical environment in parallel with the development of the Internet segment in Azerbaijan.

The interaction of Internet technologies manifested in the technologicalization of art and art in the aesthetics of Internet technologies, as well as their interdependence is very relevant in modern theatre (Aliyev, 2018: 123). It is no coincidence that the 27th World Congress of the International Association of Theatre Critics (IATC), which was held in Beijing on October 15-20, 2014, was dedicated to "The New Era: The Art of Criticism in the Internet Age" and was attended also by theatre critics and researchers from Azerbaijan. The urgency of the problem was also emphasized at the 3rd International Theatre Conference held in Baku in November 2014.

New technologies have been applied in the spectacles of Azerbaijan's leading theatres in recent years. Video footage is used in complex episodes and situations that cannot be created on stage. Today, the Academic National Drama Theatre, the flagship of the Azerbaijani theatre, presents several spectacles made with the help of this technology. But, there are some shortcomings in the use of video mapping technology in Azerbaijani theatres. First of all, it would be better if mapping is done by professional graphic designers and secondly, if the images are presented to the stage with special equipment, a higher artistic beauty is achieved. From time to time, various theatres have tried to create spectacles, to attract the attention of the audience with new methods and means. Unfortunately, the application of new technologies in the spectacles performed in our country is at a very low level. There is a great need for engineers and programmers to implement the progressive ideas of creative people working in the theatre. As we mentioned above, high-level information and communication technology professionals must be hired to realize what directors and artists want to see on stage. When talking about the cooperation of theatre and media engineers, it is worth noting an interesting fact in the Russian Federation. As a result of a joint project of the St. Petersburg National Research University of Information Technologies, Mechanics and Optics and the Russian State Academic Drama Theatre named after AS Pushkin (Alexandrinsky Theatre), multimedia and Internet technologies were applied in several spectacles. Two masters' programs on "Creation of Spectacle" and "Theatre Arts" were implemented at the Alexandrinsky Theatre and Theatre Academy and master's program "Multimedia technologies in Theatre Arts, Cinema and Television"in the direction of "Information Systems and Technologies"by St. Petersburg University (ITMO) in 2013 within the framework of the cooperation (Borisov, Burlov, Smolin, Stolyarov, Scherbakov, 2014).The mentioned experience can be successfully applied with the help of cooperation between local theatres and universities.

Of course, this work requires considerable funding. But, it should not be forgotten that the investment in a theatre is justified completely. Because of this, the theatre must raise itself to the level of a brand. Several methods that have been successfully applied in world theatres can also be used in Azerbaijani theatres.

\section{CONCLUSION}

The use of all kinds of new technologies, digital equipment and computer programs opens new opportunities for the theatre. The use of computer programs as a scenography tool and material influences the artist's style and thinking. At the same time, the artist, who is looking for more expressiveness, influences the development of the visual capabilities of computer technology. The achievements of new technologies have significantly stimulated the development of modern scenography. These achievements, in their turn, give opportunity to create a new artistic synthesis in solutions of scenography. Today, the use of various digital devices, screens and video projections controlled by computer programs are the dominant means of expression in light and image design. Digital means are replaced with the traditional tools and materials used by a theatre artist. Certain, sometimes unusual, fantastic atmosphere is created on the stage in accordance with the ideas and artistic solutions with the help of these means. But, the stage must be equipped with the necessary equipment, light and sound directors, media and programmerartists must be skilled enough in order to achieve all these ideas and visual solutions.

The use of various new technologies in scenography remains a controversial issue. Of course, computer effects can increase the number of means of artistic expression in the theatre. But at the same time, the imbalance of visual technology with artistic elements can eventually make the spectacle look like a frame 
from a film or a cheap illustration [14] (Bobrovskaya, Galkin, Sameeva, 2013: 104). Undoubtedly, the crown of the stage is the actor, the play performed by him with high mastery and skill gives the audience a great artistic pleasure and unforgettable feelings. Today, theatre and film critics argue that acting is "polluted" by new technologies in technologically advanced and developed world. Of course, new technologies are being used more in the field of cinematography. However, it should be noted that the creation of super effects using new technologies is applied more in the Hollywood film industry. Such unusual special effects are sometimes overused in movies for getting a higher income. On the other hand, unlike Hollywood films, which are rich in special effects, there are directors and films that have achieved great success at various international festivals and gained world fame without the use of any modern effects, expensive equipment and technologies. It should not be forgotten that the audience comes to the theatre to see live art. The spectator could go to the cinema to see fantastic scenes "enriched" with visual effects. Besides creating unusual effects in spectacles, the enrichment of spectacles, which have been made in the traditional style, with Internet technologies gives also positive results. But, taking into account all this, we must not forget that regardless of the level of development of media technology, it is the actor's live acting that gives the audience the most irreplaceable feeling on stage and what distinguishes theatre from other arts is its live art. This should be taken in to account and not to be forgotten by specialists who apply high technologies to the theatre.
Franco Angeli. Pp. 280.

- ГАЯКИН, Д.В. 2008. Техно-художественные гибриды, или искусство, политика и цифровые технологии в культурной динамике второй половине $\mathrm{XX}$ века. // Гуманитарная информатика. Вып. 4 Томск, С. 50-75.

- PAPAGIANNOULI, C. (2011). Cyberformance and the Cyberstage. The International Journal of the Art in Society. 6(4). 273-282.

- АСТАФЬЕВА ТАТЬЯНА ВЛАДИМИРОВНА. (2011). Компьютерные и медиа технодогии в сценографии как фактор развития постановочного процесса // Общество. Среда. Развитие (Terra Humana). №3. Стр., 129.

- БОБРОВСКАЯ.М.А, ГАЯКИН.Д.В. \& САМЕЕВА.В.С. (2013). Новые информационные технологии в современной сценографии. Гуманитарная информатика. Вып. 7. Стр., 104.

- FERAL JOSETTE. (2011). "La critique dans un paysage changeant", Theorie et Pratique du théâtre. Au-delá des limites. Montpellier: ÉditionsL'Entretemps, 54-64.

- DEEPA PUNJANI. (2014). Theatre and Theatre Criticism in a transforming age of Digital Technology. Report at the IATC Conference 2014"A New World: The Profession of Criticism in the Internet Era"

- OLIYEV ELŞAD. (2018). İnternet texnologiyalar və incəsənət. AFPoliqrAF. Bakı. Səh. 123.

- БОРИСОВ.Н.В, БУРАОВ.Д.И, СМОЯИН.А.А, СТОАЯРОВ.Д.А \& ЩЕРБАКОВ.П.П. (2014). Технологии информационного общества в науке, образовании и культуре: сборник научных статей. Материалы XVII Всероссийской объединенной конференции «Интернет и современное общество» İSM2014,Санкт-Петербург, 19-20 ноября 2014 г.

- БОБРОВСКАЯ.М.А, ГАЯКИН.Д.В. \& САМЕЕВА.В.С. (2013). Новые информационные технологии в современной сценографии. Гуманитарная информатика. Вып. 7. Стр., 104.

\section{REFERENCES}

- OLIYEV ELŞAD. Müasir Azarbaycan teatr sanati va innovativ texnologiyalar. "Şəhər və teatr" mövzusunda elmi-praktik konfransin materialları. Bakı. 04.03.2016. ADMiU-nun mətbəəsi. Səh., 15 .

- Уланова Татьяна. «Ничего не будет... Одно сплошное телевидение». Тихая слава Юрия Васильева. 12.10.2019. https:// aif.ru/culture/person/nichego_ne_budet_odno_sploshnoe_ televidenie_tihaya_slava_yuriya_vasilevaPAPAGIANNOULI CHRISTINA. 2011. Cyberformance and the Cyberstage. The International Journal of the Art in Society. 6(4), 273-282.

- CHATZICHRISTODOULOU, M. (2014). Annie Abrahams, Helen Varley Yamieson (edited by).CyPosium - the book. Link Editions. Brescia. Cyberformance? Digital or Networked Performance? Cybertheaters? Virtual Theatres?...Or All of the Above?Pag. 19-31.

- MONTEVERDI, A.M. (2010). Nuovi media, nuovo teatro. Milano. 